\title{
PREFACE TO THE REVISED EDITION
}

THE FIELD wORK on which the original version of this study was based was carried out during a seven-months sojourn in Colombia in I946, with headquarters in Medellín. I would here reiterate my deep sense of gratitude and affection to Professor Carl O. Sauer, my mentor for half a lifetime, who originally directed my interests towards Antioquia as a distinctive culture area, and who has been a continuing source of intellectual stimulation and guidance ever since. Among many genial Antioqueño hosts I would again single out Luis Ospina Vásquez and the late Dr. Emilio Robledo and Gabriel Arango Mejía, all Medellinenses, whose kind counsel and assistance is reflected throughout these pages.

Since the appearance of the first edition of this work (University of California: Ibero-Americana, vol. 32, 1949), and the later Spanishlanguage versions, so generously translated and annotated by Dr. Robledo (La Colonización Antioqueña en el Occidente de Colombia, Medellín, I950; revised, Bogotá, 1961), great change has come to the Antioqueño countryside. The extent and pace of this change perhaps comes even more forcibly to the attention of the returning visitor than it does to the permanent resident. In the last two decades Medellín has evolved from an isolated provincial capital to a metropolitan conurbation of more than a million persons. Indeed, it has recently occurred to me that more than half of the present population of Antioquia and Caldas had not yet been born at the time I took my first stroll across the Parque Berrío in 1946. But notwithstanding the very rapid rate of population increase, so characteristic of most of Latin America, the level of living and literacy in Antioquia has continued to climb at a pace substantially above the average.

The reception given the original version of this work by Colombians has encouraged me to prepare a second English-language edition. Several visits to Colombia over the intervening years have provided the bases for many of the revisions and alterations in the original text, but $I$ have drawn equally upon the considerable literature on the regional geography and social history of western Colombia that has appeared since 1949. Especially noteworthy have been the works of Ernesto Gühl, Everett E. Hegen, Luis Ospina Vásquez, and 
Robert C. West. These and other important contributions of direct relevance to the subject of this study that have appeared since the first edition, are listed in the supplementary bibliography, pp. ooo. Colombia's I 964 Census of Population and the 1964 Census of Manufactures, although not yet available in final form, have been used to update much of the statistical data. My recent monograph on Antioquia's Corridor to the Sea: An Historical Geography of the Settlement of Urabá (University of California: Ibero-Americana, vol. 49, I967) further expands on some of the themes originally developed in this volume.

The principal substantive changes and additions in this second edition will be found in the sections on population growth, transportation, and industrial development (chapters 8, I1, and 12). Parts of chapters 4,6 , and io have also been revised, and the text throughout has been brought up-to-date wherever possible. A few notes and a somewhat larger number of bibliographic citations also have been added. Maps 8, 9, and 13 have been redrawn and several of the photographic plates at the back have been replaced by others. These changes have not significantly altered the sense of the original thesis, essentially a delineation in historical perspective of the distinctive Antioqueño culture and economy and the extent and character of its geographic spread.

J. J.P.

August, 1967 